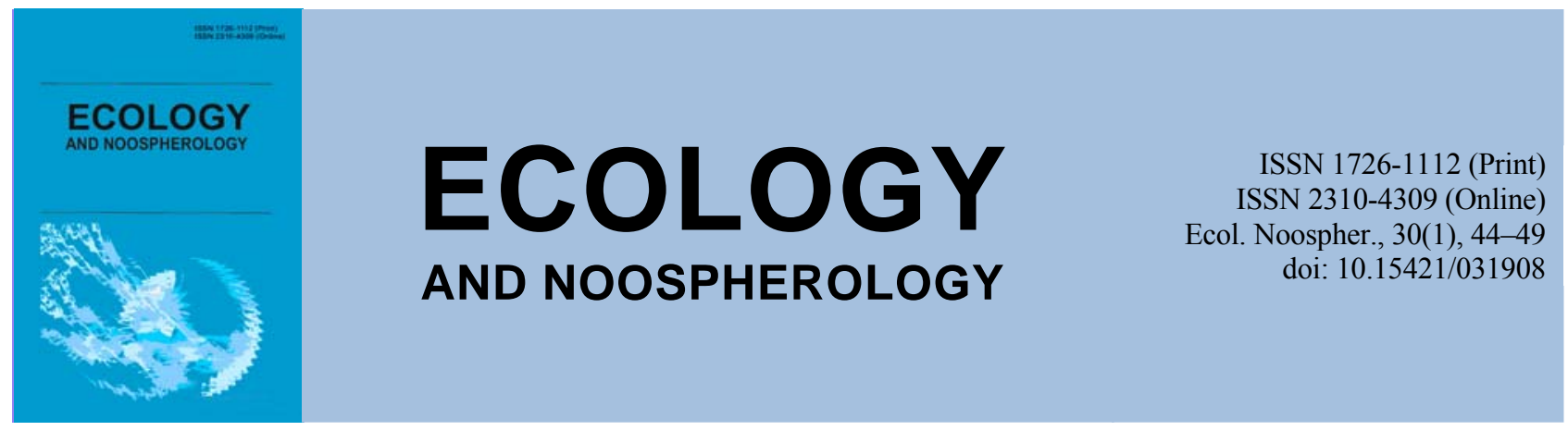

\title{
The reaction of soybean symbiotic apparatus to losses of water content in leaves and roots, induced by continuous action of drought
}

\author{
T. P. Mamenko
}

Institute of Plant Physiology and Genetics of National Academy of Sciences of Ukraine, Ukraine

Article info

Received 15.02.2019

Received in revised form 24.02.2019

Accepted 02.03.2019

Institute of Plant Physiology and Genetics of National Academy of Sciences of Ukraine,

Str. Vasylkivska, 31/17, Kyiv, 03022, Ukraine.

Tel.: +38-050-964-17-89

E-mail:t_mamenko@ukr.net

\begin{abstract}
Mamenko, T. P. (2019). The reaction of soybean symbiotic apparatus to losses of water content in leaves and roots, induced by continuous action of drought. Ecology and Noospherology, 30(1), 44-49. doi:10.15421/031908
\end{abstract}

The reaction of the soybean symbiotic apparatus inoculated with Bradyrhizobium japonicum strains and Tn5 mutants, which were different in efficiency, was studied for the loss of water content in leaves and roots induced by prolonged drought, as well as the seed productivity of the formed symbiotic systems. To conduct researches were used microbiological, physiological, biochemical methods, gas chromatography and spectrophotometry. The objects of the study were selected symbiotic systems formed with the participation of soybean plants and strains B. japonicum 646 (active, virulent) and 604k (inactive, highly virulent), as well as Tn5-mutants - B1-20 (active, virulent) and 107 (lowactive, virulent) obtained by the method of transposon mutagenesis in the department of symbiotic nitrogen fixation at the Institute of Plant Physiology and Genetics of the National Academy of Sciences of Ukraine. Before sowing, sterilized with $70 \%$ ethanol and washed under running water for $1 \mathrm{~h}$, the seeds were inoculated with suspensions of nodules bacteria (the titre of the suspension was $10^{8}$ cells in $1 \mathrm{ml}$ ). The combined model drought was created during 12 days by stopping watering of plants up to $40 \%$ of full moisture content starting from the stage of two true leaves and gradual transfer of watering to $30 \%$ of full moisture content in the stage of three true leaves and budding - the beginning of flowering. After the stopping of drought, the moisture content of the substrate was adjusted to $60 \%$ of full moisture content (watering recovery) into the stage of mass flowering. Control plants were inoculated by rhizobium culture, as well as plants without inoculation, which grew for optimal watering. It was investigated that in symbiotic systems formed with the participation of soybean and the active strain B. japonicum (646) and Tn5-mutant (B1-20) there was no significant reduction in the water content of plants under drought conditions and the effective work of the symbiotic apparatus was recorded, which contributed to the preservation of seed productivity. Ineffective symbiotic systems observed significant losses in water content and inhibition of the process of nodulation (strain 604k) and nitrogen fixation (Tn5-mutants 107), which was accompanied by significant losses of soybean crop yields. As a result of the research, it was concluded that in soil-climatic conditions with insufficient rainfall and frequent droughts, effective symbiotic systems should be used, which will promote the optimal functioning of the symbiotic apparatus and preserve the seed productivity of soybeans by adaptive regulation of water balance and fixation of molecular nitrogen of the atmosphere. The study of the functioning of leguminous plants in symbiosis with strains of nodule bacteria is important for finding effective symbiotic systems that are able to realize their adaptive potential for the effects of stress factors, in particular drought. Effective symbiotic relationships are the main source of nitrogen fixation in terrestrial ecosystems, which will reduce the need to enrich the soil with chemical compounds and provide additional economic and environmental advantage.

Keywords: Bradyrhizobium japonicum; soy (Glycine $\max$ (L.) Merr.); relative water content; nitrogen fixation activity; drought 


\title{
Реакція симбіотичного апарату сої на втрати вмісту води у листках і коренях, індуковані тривалою дією посухи
}

\author{
Т. П. Маменко \\ Інститут фізіології рослин і генетики Національної академії наук Украӥни, Київ, Украӥна
}

У результаті проведених досліджень зроблено висновок, що в грунтово-кліматичних умовах із недостатньою кількістю опадів та частими посухами слід використовувати ефективні симбіотичні системи, що сприятиме оптимальному функціонуванню симбіотичного апарату та збереженню зернової продуктивності сої за рахунок адаптивної регуляції водного балансу та фіксації молекулярного азоту атмосфери. Вивчення особливостей функціонування бобових рослин у симбіозі із штамами бульбочкових бактерій $\epsilon$ важливим для пошуку ефективних симбіотичних систем, які здатні реалізувати свій адаптивний потенціал за дії стрес-факторів, зокрема посухи.

Ключові слова: Bradyrhizobium japonicum, соя (Glycine max (L.) Merr.), відносний вміст води, азотфіксувальна активність, посуха

\section{Вступ}

Ріст і розвиток рослин визначаються впливом факторів навколишнього середовища, таких як висока та низька температура, посуха, засолення тощо. У відповідь на абіотичні стреси рослини проходять різноманітні зміни на молекулярному рівні (генна експресія), що призводить до фізіологічної адаптації (Zheng et al., 2010; Ashraf and Foolad, 2013, Wei et al., 2009). Посуха $є$ основним абіотичним стресором, який суттєво впливає на врожай та якість сільськогосподарських культур у багатьох регіонах світу, що загрожує продовольчій безпеці. Ситуація стала більш серйозною із постійними глобальними змінами клімату. Тому вивчення стресової толерантності рослин до абіотичних факторів, у тому числі й посухи, стало одним із пріорітетних напрямів досліджень в усьому світі.

Проблема реалізації потенційної продуктивності рослин за дії несприятливих факторів довкілля $є$ однією із основних у забезпеченні високих врожаїв сільськогосподарських рослин. Незважаючи на значну кількість робіт, присвячених вивченню окремих аспектів стійкості рослин до дії стресових факторів, залишаються малодослідженими питання фізіолого-генетичних механізмів, які визначають функціональний стан та реалізацію потенційної продуктивності культурних рослин за несприятливих умов середовища. Останні досягнення щодо вивчення питання посухостійкості включають розкриття фізіологічних, біохімічних та молекулярних механізмів стрес-толерантності рослин (Ashraf et al., 2010, Niu et al., 2012, Chen et al., 2007; Smethurst et al., 2009).

Бобові культури за посівними площами та валовими зборами у світовому землеробстві займають друге місце після зернових. Вони $є$ важливим джерелом високоякісного білка для харчування як людей, так i тварин (Rogers et al., 2009). Завдяки симбіотичним зв'язкам між бактеріями родини Rhizobiaceae та бобовими рослинами останні забезпечуються атмосферним азотом (Morgun and Kots, 2018). Біологічна фіксація азоту забезпечує бобові та грунти додатковим джерелом азоту, що має особливо велике значення для збіднілих грунтів.

Симбіотичні взаємовідносини між рослиною та бактеріями відбуваються в кореневих бульбочках, у яких бактерії є ізольованими від клітини-хазяїна симбіосомою мембраною, що регулює обмін між обома симбіонтами (Andrews and Andrews, 2017). Регулювання активності нітрогенази, а отже i наявність азоту в рослинах обумовлено надходженням вуглецю до бактероїдів (Gálvez et al.,2005; Larrainzar et al., 2009). Тому існує тісна залежність між метаболізмом вуглецю і азоту, а отже між бактероїдними речовинами та тими, що продукуються рослиною. Рослина-хазяїн забезпечує надходження в кореневі бульбочки фотоасимілятів, які є джерелом енергії i вуглецю та необхідні для фіксації азоту за рахунок нітрогеназного комплексу (Cerezini, 2016; Kots, 2010; McCormick, 2018).

Досліджено, що на рівні листка водний стрес викликає гальмування фотосинтезу, зумовлене закриттям продихів i зниженням активності ферменту Рубіско. Зниження постачання сполук вуглецю призводить до накопичення сахарози та зниження концентрації органічних кислот, головним чином у вигляді малату, що викликає дефіцит субстрату для бактеріального дихання (Muller et al., 2011; Fathi et al., 2016). Як наслідок, відбувається накопичення кисню в інфікованій зоні, що призводить до збільшення в опорі дифузійного бар'єру кисню, щоб уникнути пошкодження нітрогенази. В обох випадках як виснаження дихальних шляхів, так і наступне зниження дифузійного бар'єру кисню може призвести до зниження фіксації азоту (Aranjuelo et al., 2014; Jemo, 2017).

Переважна більшість досліджень присвячена аналізу ефективності процесів, що відбуваються у кореневих бульбочках, не враховуючи інших органів рослини. Тому особливу увагу слід звернути на вивчення процесу фіксації азоту як взаємного обміну рослинно-бактеріальними ресурсами. Зокрема, експерименти з маркування показали, що фотоасиміляти із листків швидко (протягом 1 години) переносяться в кореневі бульбочки (Aranjuelo et al., 2014). Результати доводять, що фактори зміни властивостей листків впливають на функціонування бульбочок і навпаки, а також підкреслюють важливість розгляду взаємодії в цілому рослини і бактерій (Sulieman and Tran, 2014; Kunert, 2016).

Дослідження функціонування інших органів рослини (а не лише кореневих бульбочок) та взаємодії між ними можуть поглибити знання про регуляцію процесів функціонування бульбочок та їх обмін метаболітами із рослиною. Ця інформація може бути корисною для кращого розуміння комунікації рослина - бульбочка і використана в подальших дослідженнях, спрямованих на пошук ефективних симбіотичних систем, краще адаптованих до різноманітних змін клімату (Aranjuelo et al., 2014; Jemo, 2017). Вивчення впливу різної за інтенсивністю та тривалістю посухи на ріст $\mathrm{i}$ розвиток рослин $\epsilon$ важливим не лише для розуміння їх відповіді на дію стресора, а й в оцінці здатності рослин у симбіозі із бульбочковими бактеріями до акліматизації.

Метою досліджень було вивчити реакцію симбіотичного апарату сої, інокульованої різними за ефективністю штамами та Tn5-мутантами Bradyrhizobium japonicum на втрати вмісту води в листках i коренях, індуковані тривалою посухою, а також зернову продуктивність утворених симбіотичних систем.

\section{Матеріали і методи досліджень}

У роботі використано штами $B$. japonicum із музейної колекції азотфіксуючих мікроорганізмів Інституту фізіології рослин і генетики НАН України (ІФРГ НАНУ) - 
646 (активний, вірулентний) та 604к (неактивний, високовірулентний), а також Tn5-мутанти - B1-20 (активний, вірулентний) та 107 (малоактивний, вірулентний), отримані методом транспозонового мутагенезу у відділі симбіотичної азотфіксації ІФРГ НАНУ. Культуру повільнорослих бульбочкових бактерій вирощували на твердому манітно-дріжджовому середовищі протягом 7 діб при 26-28 ${ }^{\circ} \mathrm{C}$ до початку стаціонарної фази росту. Перед посівом простерилізоване 70\%-ним етанолом і промите під проточною водою протягом 1 год насіння інокулювали суспензіями бульбочкових бактерій (титр суспензії становив $10^{8}$ кл/мл).

Рослини сої (Glycine max (L.) Merr.) сорту Алмаз вирощували у 10-кілограмових посудинах у піщаній культурі із внесенням поживної суміші Гельрігеля з 0,25 норми азоту за природнього освітлення та оптимального водозабазпечення (60 \% повної вологоємкості (ПВ)). Комбіновану модельну посуху створювали впродовж 12 діб одночасним припиненням поливу рослин до $40 \%$ ПВ починаючи $з$ фази двох справжніх листків та поступовим переведенням поливу до 30 \% ПВ у фази трьох справжніх листків та бутонізації - початку цвітіння. Після припинення дії посухи вологість субстрату в посудинах доводили до 60 \% ПВ (відновлення поливу) у фазу масового цвітіння. Контролем слугували інокульовані ризобіями рослини сої, а також рослини без інокуляції, що зростали за оптимального поливу (60 \% ПВ).

Втрати вмісту води у листках і коренях оцінювали за динамікою величини оводненості (OB) або відносного вмісту води шляхом висушування зразків до постійної маси при температурі $+105{ }^{\circ} \mathrm{C}$. Нодуляційну здатність B. japonicum визначали за підрахунком кількості та маси кореневих бульбочок, азотфіксувальну активність (АФА) ацетиленовим методом на газовому хроматографі «Agilent GC system 6850» (США) з полуменево-іонізаційним детектором (Hardy et al, 1968). Розділення газів проводили на колонці (Supelco Porapak N) за температури термостата $55{ }^{\circ} \mathrm{C}$ і детектора $-150{ }^{\circ} \mathrm{C}$. Газом-носієм був гелій $(20$ мл за 1 хвилину). Об'єм аналізованої проби газової суміші становив $1 \mathrm{~cm}^{3}$. Як стандарт використовували чистий етилен (Sigma-Aldrich, № 536164, США). Повторність визначень показників ОВ і АФА - 10-кратна, обліку врожаю - 5 посудин на варіант з розрахунку по 16 рослин у кожній посудині. Одержані дані оброблені статистично 3 використанням критерію Стьюдента.

\section{Результати та їх обговорення}

Установлено, що посуха індукувала суттєві втрати вмісту води в листках і коренях рослин сої. При цьому ОВ у різних органах рослин сої знижувалась із посиленням впливу стресового фактора, зокрема в листках на $40 \%$, а в коренях на $20 \%$ (табл. 1).

У рослинах сої, проінокульованої активними штамом B. japonicum 646 i Tn5-мутантом В1-20, втрати вмісту води у листках були незначними і становили до $20 \%$ за тривалої дії посухи у фазу бутонізації. За таких умов у сої, інокульованої малоактивним $\operatorname{Tn} 5$-мутантом 107, а також неактивним штамом $B$. japonicum 604к, ОВ листків знижувалась на $30 \%$. При цьому не відзначено суттєвих втрат вмісту води в коренях сої за умов посухи, незалежно від ефективності симбіотичних систем.

Після відновлення поливу у фазу масового цвітіння інтенсивніше відновлення вмісту води відбувалось у рослинах, які були інокульовані активними штамом ризобій 646 і Tn5-мутантом B1-20, у порівнянні із неінокульованими рослинами та інокульованими малоефективним $\operatorname{Tn} 5$-мутантом 107 i неефективним штамом 604к.

Зафіксовано, що за помірної дії посухи у фазу трьох справжніх листків у сої, інокульованої активним штамом ризобій 646, не спостерігалось зниження кількості кореневих бульбочок, проте їх маса зменшувалась майже вдвічі. Водночас у рослин, інокульованих активним Tn5мутантом В1-20, відмічено зниження як маси бульбочок (до $80 \%$ ), так і їх кількості (до 30 \%) (табл. 2). За подальшого впливу дефіциту вологи у фазу бутонізації у цих симбіотичних системах не відбувалось суттєвого пригнічення бульбочкоутворення. Зокрема, кількість кореневих бульбочок знижувалась на $20 \%$, а їх масса - на $30-40 \%$ у порівнянні із рослинами, які зростали за оптимальних умов поливу. Такі дані вказують на високий адаптаційний потенціал утворених симбіотичних систем.

Виявлено пригнічення процесів нодуляції на коренях сої, інокульованої малоактивним Tn5-мутантом 107, вже на початкових етапах зневоднення, що було обумовлено суттєвим зниженням маси кореневих бульбочок (до $90 \%$ ) та їх кількості (до 70 \%). Така тенденція зберігалась за тривалої дії посухи. У симбіозі сої із неактивним штамом ризобій 604к відмічено пригнічення бульбочкоутворення зменшення кількості (до 60 \%) та маси (до $95 \%$ ) бульбочок на коренях рослин за тривалої дії посухи.

Досліджено, що помірна посуха у фазу трьох справжніх листків приводила до зниження загальної АФА кореневих бульбочок (на 20 \%) у симбіотичній системі, утвореній за участю активного штаму ризобій 646 (табл. 3). За тривалого дефіциту вологи у фазу бутонізації цей показник знижувався на 50 \%. У симбіотичній системі, утвореній за участю активного Tn5-мутанта В1-20, загальна АФА кореневих бульбочок пригнічувалась до $60 \%$ впродовж дії посухи. Водночас питома АФА кореневих бульбочок зростала в ефективних симбіотичних системах (на $70-80 \%$ ) на початкових етапах зневоднення та незначно знижувалась (на $30 \%$ ) за тривалого зневоднення, що свідчить про збереження функціонування симбіотичного апарату.

Посуха індукувала суттєве зниження (до 90 \%) показників загальної і питомої АФА кореневих бульбочок у рослин, інокульованих малоактивним Tn5-мутантом 107. Після відновлення поливу рослин у фазу масового цвітіння відбувалось інтенсивніше відновлення водного балансу та функціонування симбіотичного апарату у рослин, інокульованих активними штамом ризобій 646 i Tn5мутантом В1-20.

Посуха призводила до значних втрат врожаю сої у неінокульованих рослин, а також у тих, які були інокульовані малоактивним Tn5-мутантом B. japonicum 107 і неактивним штамом 604к (рис. 1). Втрати врожаю зерна в зазначених варіантах становили до $50 \%$ і більше. У рослин, інокульованих активними штамом $B$. japonicum 646 i Tn5-мутантом B1-20, зернова продуктивність знижувалась до 25-30 \%.

Аналіз отриманих результатів показав, що зміни у водному балансі, індуковані посухою, супроводжувались значними порушеннями в роботі симбіотичного апарату, про що свідчить зниження нодуляційної здатності та азотфіксувальної активності бульбочкових бактерій у симбіозі із рослинами сої. При цьому міра негативного впливу посухи на процеси нодуляції та азотфіксації залежала від тривалості дії стресора та адаптаційного потенціалу утвореної симбіотичної системи.

Досліджено, що в симбіотичних системах, утворених за участю сої та активних штаму $B$. japonicum (646) i Tn5мутанту (В1-20), не відбувалось суттєвого зниження оводненості рослин за умов посухи та зафіксовано ефективну роботу симбіотичного апарату, що сприяло збереженню зернової продуктивності. У неефективних симбіотичних системах спостерігались значні втрати вмісту води та пригнічення процесів нодуляції (штам 604к) й азотфіксації (Tn5-мутант 107), що супроводжувались значними втратами врожаю сої. 


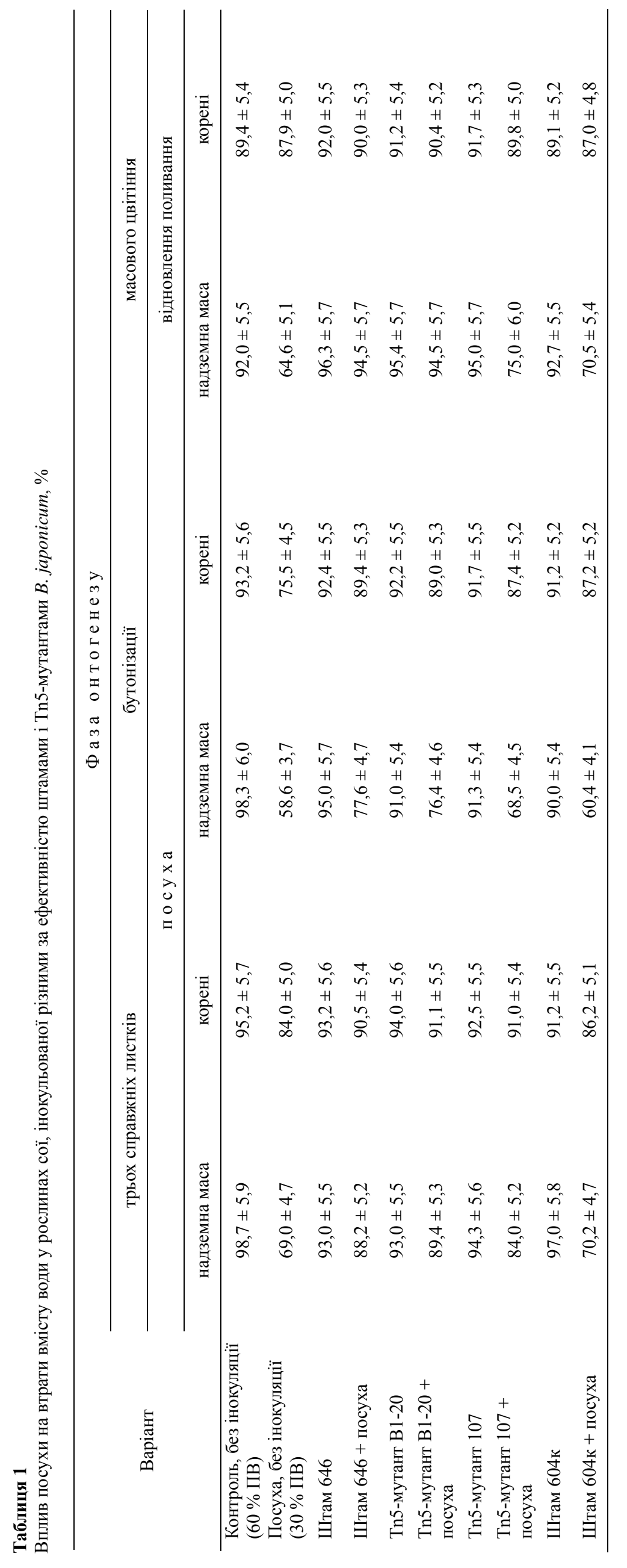



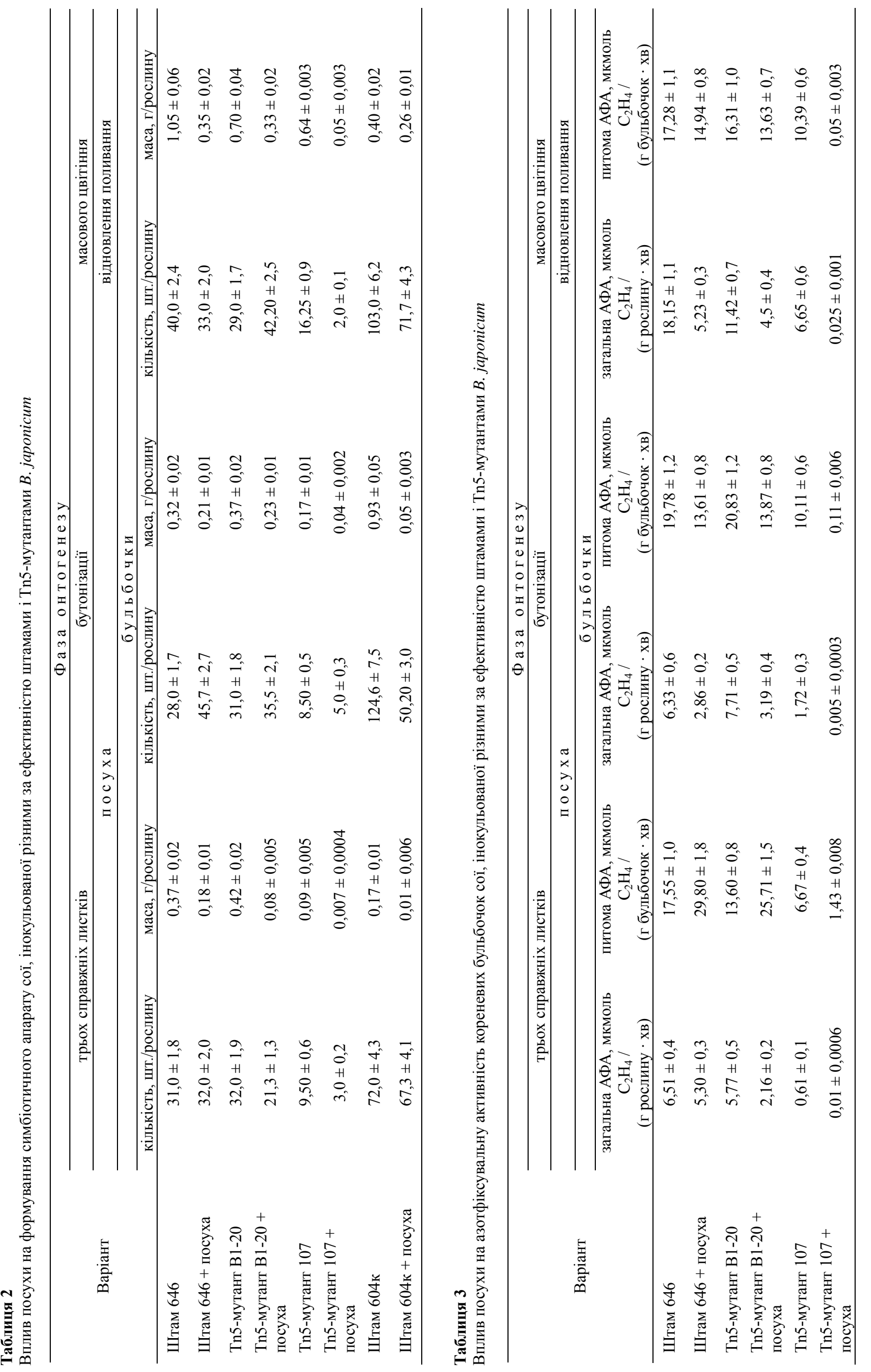


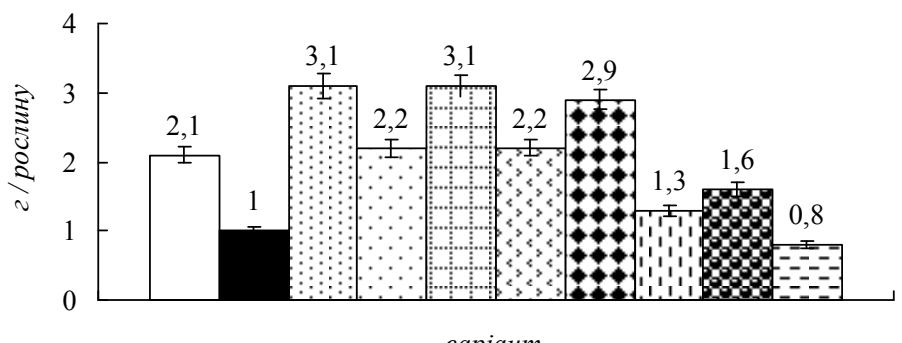

\begin{tabular}{|c|c|}
\hline & заріант \\
\hline $\begin{array}{l}\square \text { Контроль, без інокуляції (60 \% ПВ) } \\
\square 646 \\
\square \text { В1-20 } \\
107 \\
\mathbf{8} 604 \kappa\end{array}$ & $\begin{array}{l}\text { Посуха, без інокуляції (30 \% ПВ) } \\
646+\text { посуха } \\
\text { В1-20+ посуха } \\
107+\text { посуха } \\
\text { 1004к + посуха }\end{array}$ \\
\hline
\end{tabular}

Рис. 1. Вплив посухи на зернову продуктивність сої,

інокульованої різними за ефективністю штамами і Tn5-мутантами $B$. japonicum

\section{Висновки}

У грунтово-кліматичних умовах із недостатньою кількістю опадів та частими посухами слід використовувати ефективні симбіотичні системи, що сприятиме оптимальному функціонуванню симбіотичного апарату та збереженню зернової продуктивності сої за рахунок адаптивної регуляції водного балансу та фіксації молекулярного азоту атмосфери. Вивчення особливостей функціонування бобових рослин у симбіозі із штамами бульбочкових бактерій $\epsilon$ важливим для пошуку ефективних симбіотичних систем, які здатні реалізувати свій адаптивний потенціал за дії стрес-факторів, зокрема посухи.

\section{References}

Andrews, M., Andrews , M. E. (2017). Specificity in LegumeRhizobia Symbioses. International Journal of Molecular Science, 18(4), 1-39. DOI: 10.3390/ijms18040705.

Aranjueloa, I., Arrese-Igor, C., Gemma, M. (2014). Nodule performance within a changing environmental context. J. of Plant Physiology, 171, 1076-1090. DOI: 10.1016/j.jplph.2014.04.002.

Ashraf, M. A., Ashraf, M., Ali, Q. (2010). Response of two genetically diverse wheat cultivars to salt stress at different growth stages: leaf lipid peroxidation and phenolic contents. J. Bot., 42(1), 559-565. DOI: 10.15666/aeer/1405_091105.

Ashraf, M., Foolad, M. R. (2013). Crop breeding for salt tolerance in the era of molecular markers and marker-assisted selection. Plant Breeding., 132(1), 10-20. DOI: 10.1111/pbr.12000.

Cerezini, P., Riar, M. K., Sinclair, T. R. (2016). Transpiration and nitrogen fixation recovery capacity in soybean following drought stress. J. Crop Improv., 30, 562-571. DOI: 10.1080/15427528.2016.1196469.

Chen, Z. H., Zhou, M. X., Newman, I. A., Mendham, N. J., Zhang, G. P., Shabala, S. (2007). Potassium and sodium relations in salinised barley tissues as a basis of differential salt tolerance. Funct. Plant Biol., 34, 150-162. DOI: 10.1104/pp.107.110262.

Fathi, A., Tari, D. B. (2016). Effect of Drought Stress and its Mechanism in Plants. International Journal of Life Sciences, 10(1), 1-6. DOI: 10.3126/ijls.v10i1.14509.

Gálvez, L., González, E. M., Arrese-Igor, C. (2005). Evidence for carbon flux shortage and strong carbon/nitrogen interactions in pea nodules at early stages of water stress. J Exp Bot., 56, 2551-2561. DOI: 10.1093/jxb/eri249.

Hardy, R. W. F., Holsten, R. D., Jackson, E. K., Burns, R. C. (1968). The acetylene-ethylene assay for nitrogen fixation: laboratory and field evolution. Plant Physiol., 43(8), 1185-1207.

Jemo, M., Sulieman, S., Bekkaoui, F., Oluwatosin, A. K., Olomide, A. H., Allah, E. F. A., Alqarawi, A. A., Tran, L. S. P. (2017). Comparative analysis of the combined effects of different water and phosphate levels on growth and biological nitrogen fixation of nine cowpea varieties. Front. Plant Sci., 8(2111), 1-16. DOI: 10.3389/fpls.2017.02111.

Kots, S. Ya., Morgun, V. V., Patyka, V. F. (2010). Biolohichna fiksatsiya azotu: bobovo-ryzobialnyy symbioz [Biological fixation of nitrogen: bean-rhizobial symbiosis]. Logos, Kyiv (in Ukrainian).

Kunert, K. J., Vorster, B. J., Fenta, B. A., Kibido, T., Dionisio, G., Foyer, C. H. (2016). Drought stress responses in soybean roots and nodules. Front. Plant Sci., 7, 1-7. DOI: 10.3389/fpls.2016.01015.

Larrainzar, E., Wienkoop, S., Scherling, C., Kempa, S., Ladrera, R., Arrese-Igor, C. (2009). Carbon metabolism and bacteroid functioning are involved in the regulation of nitrogen fixation in Medicago truncatula under drought and recovery. Mol Plant Microbe Interact., 22, 1565-1576. DOI: 10.1094/MPMI-22-12-1565.

McCormick, S. (2018). Rhizobial strain - dependent restriction of nitrogen fixation in a legume - Rhizobium symbiosis. The Plant Journal, 93(1), 3-4. DOI: 10.1111/tpj.13791.

Morgun, V. V., Kots, S. Ya. (2018). Rol biolohichnoho azotu u azotnomu zhyvlenni roslyn [Role of biological nitrogen in nitrogen feeding of plants]. Visn. Nac. Akad. Nauk Ukr., 1, 62-71 (in Ukrainian). DOI: 10.15407/visn2018.01.062.

Muller, B., Pantin, F., Génard, M., Turc, O., Freixes, S., Piques, M. (2011). Water deficits uncouple growth from photosynthesis, increase $\mathrm{C}$ content, and modify the relationships between $\mathrm{C}$ and growth in sink organs. J Exp Bot., 62, 1715-29. DOI: $10.1093 / \mathrm{jxb} / \mathrm{erq} 438$.

Niu, C. F., Wei, W., Zhou, Q. Y., Tian, A. G., Hao, Y. J., Zhang, W. K., Ma, B., Lin, Q., Zhang, Z. B., Zhang, J. S., Chen, S. Y. (2012). Wheat WRKY genes TaWRKY2 and TaWRKY19 regulate abiotic stress tolerance in transgenic Arabidopsis plants. Plant Cell Environ., 35(6), 1156-1170. DOI: 10.1111/j.1365-3040.2012.02480.x.

Rogers, A., Gibon, Y., Stitt, M., Morgan, P. B., Bernacchi, C. J., Ort, D. R. (2006). Increased C availability at elevated carbon dioxide concentration improves $\mathrm{N}$ assimilation in a legume. Plant Cell Environ., 29, 1651-1658.

Smethurst, C. F., Gill, W. M., Shabala, S. (2009). Using excised leaves to screen lucerne for salt tolerance: Physiological and cytological evidence. Plant Signal Behav., 4(1), 39-41.

Sulieman, S., Tran, L-S. P. (2014). Symbiotic Nitrogen Fixation in Legume Nodules: Metabolism and Regulatory Mechanisms. Int J Mol Sci., 15(11), 19389-19393. DOI: 10.3390/ijms151119389.

Wei, B., Jing, R., Wang, Ch., Chen, J., Mao, X., Chang, X., Jia, J. (2009). Dreb1 genes in wheat (Triticum aestivum L.): development of functional markers and gene mapping based on SNPs? Mol. Breed., 23, 13-22. DOI: 10.1007/s11032-008-9209-z.

Zheng, J., Fu, J., Gou, M., Huai, J., Liu, Y., Jian, M., Huang, Q., Guo, X., Dong, Z., Wang, H., Wang, G. (2010). Genome-wide transcriptome analysis of two maize inbred lines under drought stress. Plant Mol Biol., 72, 407-423. DOI: 10.1007/s11103009-9579-6. 